\title{
ONKO YHÄ OLTAVA EHDOTTOMAN MODERNI? HUOMIOITA ESTEETTISESTÄ TEORIASTA
}

\begin{abstract}
THEODOR ADORNO: Esteettinen teoria. Suom. Arto Kuorikoski. Tampere: Vastapaino, 2006.
\end{abstract}

Theodor Adornon (1903-1969) viimeiseksi työksi jäi hänen suuri taidetta käsittelvä kirjansa Ästhetische Theorie. Kirjan keskeneräiseksi jäänyt käsikirjoitus julkaistiin postuumisti Rolf Tiedemannin ja Adornon lesken Gretelin toimittamana vuonna 1970. Kirjan ulkoasu on erikoinen tavalla, jota sen keskeneräisyys ei selitä. Walter Benjaminin mukaan filosofisen kirjoituksen kuuluu asettaa kysymys esityksestä (Frage der Darstellung) uudelleen joka käänteessä. Adorno pysyi ajatukselle uskollisena ja näyttää viimeisinä vuosinaan hahmotelleen filosofisen kirjoituksen mallia, jolle esityksen kysymisestä tulee eräänlainen muotolaki. Hän kirjoittaa pikemminkin sarjallisesti kuin argumentatiivisesti: aiheet toistuvat ja lomittuvat, teemat muistuttavat jatkuvasti toisiaan, mutta eroavat alati yksityiskohdissaan. Tämä jättää jälkensä kirjoituksen ulkoasuun. Teosta selaillen löytää nopeasti aukeaman, jolla yksikään kappalejako ei katkaise tekstimassaa. Pitkät, polveilevat lauseet kaatuvat vasemmalta oikealle ja ylhäältä alas kuin hyöky, jota vain harvoin katkoo piste tai puolipilkku. Tekstin hengitys, johon Benjamin samaten kiinnittää huomionsa, on tässä kirjassa venytetty kohti epäihimillistä kestoa, ja se alkaa piankin painaa ja ahdistaa lukijan rintaa. Tämä ahdistus on kahtalaista. Yhtäältä teksti jatkuu ja toistuu, soutaa ja huopaa, naaraa samoja aiheita yhä uudelleen, sukeltaa pitkiksi ajoiksi pinnan alle ja nousee lopulta näkyville osapuilleen siellä, missä se viimeksi nähtiinkin, ilman että mitään merkittävää näyttäisi tarttuneen uppeluksissa mukaan. Toisaalta tätä jaanaamista kuvioi rauhaton hyperventilointi. Kirjoittaja tuntuu usein ahtavan pieneen tilaan keskenään ristiriitaisia näkemyksiä, mikä saa lukijan odottamaan niiden ratkaisua, mutta tällaiset toiveet petetään toistuvasti. Pikemminkin näkökulmien kasaantuessa teksti jo laukkaa eteenpäin, kohti uutta vastakkainasettelua. Kirjan laajuus voimistaa vaikutelmaa tempojen kummasta yhdistelmästä ja tuottaa erikoisen vaikutelman. Tuntuu kuin oltaisiin jatkuvasti niin syvällä "itse asiassa", että yhteys arkitodellisuuteen alkaisi horjua. Samalla asia itse tuntuu kuitenkin olevan oudosti asian vierestä, jotenkin tavoittamattomissa. Lukijaa kohtaa tässä vaiheessa houkutus ottaa teksti eräänlaisena ylimitoitettuna ja vaikeaselkoisena mielipidekirjoituksena, jossa esitetään monenlaisia näkemyksiä taideja kulttuuriasioista. Tässä esittelyssä yritän näyttää, miksi tämä lukutapa on mielestäni kuitenkin puutteellinen ja suorastaan huonokin tapa lähestyä Esteettistä teoriaa.

Vuonna 2006 julkaistun suomenkielisen laitoksen lukijan avuksi ei voi ikävä kyllä tarjota alkuperäistekstiin sisältyvää hauskaa mahdollisuutta ottaa teksti eräänlaisena ratkeamattomana jännitysnäytelmänä tai modernistisena dekkarina jonka päähenkilöt kuten Ausdruck, Beckett, Beethoven, Form, Hegel, Kafka, Kant, Kunst, Mimesis, Philosophie ja Wahrheit erottuvat tekstivyörystä isojen alkukirjaintensa ansiosta. Vaikka moni tärkeä hahmo jäi mainitsematta, on tässä yksi avain kirjan lukemiseen: se on kuin näyttämö, jolla tietty joukko hahmoja yhä uusissa kohtauksissa selvittelee suhteitaan. Teoriat ja teokset näyttävätkin olevan Adornolle jotakin kvasielollista: syntyviä, toimivia, vanhenevia ja kuolevia asioita historian virrassa. Tämä elollistava näkökulma voidaan ymmärtää tasapainottavaksi tekijäksi tarkasteltaessa Adornon epäinhimillistä lähenevää kirjoitusta, joka on tietoinen luonteestaan kirjoituksena, kuolleena ja kuolettavana. Tämä personalisoivan ja kuolettavan vastapoolista lähtien Adorno rakentelee toisteisia skenaarioita, jotka ikään kuin varioivat pääasetelmia. Vaikka kirjassa onkin selvästi erillisiä näytöksiä ja jopa muutama väliaika, ei valmista esitystä kuitenkaan ole luvassa. Lieneekin syytä valmistautua kysymään, miten katsojina tai lukijoina voisimme ottaa Esteettisen teorian esityksen vastaan, jotta se ei - ainakaan ainoastaan pettäisi odotuksiamme. Ehkä sen puutteelliselta vaikuttava esitys sittenkin tarjoaisi jotain merkittävää? Tämän ajatuksen pohjustukseksi ja kiertotienä siihen esitän seuraavaksi lyhyen katsauksen siitä, millaisen vastaanoton $A ̈ s t$ hetische Theorie sai ilmestyessään.

\section{I}

Länsi-Saksan poliittinen tilanne oli kiristynyt koko 1960luvun jälkipuoliskon: poliittisesti tiedostavalla opiskelijanuorisolla oli vastassaan isien sukupolvi, joka taloudellisessa noususuhdanteessa oli haluton käymään läpi omaa suhdettaan natsihallinnon kauteen. Tämän trauman läpikäyntiä julkisissa puheenvuoroissaan voimakkaasti ajaneesta Adornosta tuli yksi opiske- 
lijaliikkeen keskeisistä auktoriteeteista. Yhteisymmärrys oli kuitenkin alusta asti rajallista. Länsi-Saksan tuki Vietnamin sotaa käyville Yhdysvalloille, valtapuolueiden yhdistyminen oppositiopolitiikan mahdollisuudet tukkivaksi gonglomeraatiksi, yliopistolakiuudistuksen epädemokraattiset tendenssit, poliisin väkivaltaisuus ja konservatiivisen lehdistön provokaatiot romuttivat opiskelijaliikkeen uskoa yhteiskunnallisiin instituutioihin. Yhteiskuntajärjestyksen suorasta haastamisesta oli puolestaan muodostunut eräänlainen tabu Adornon omalle kriittisen teorian variantille, joka etsi tarkastelukulmaa sosiaaliseen pikemminkin esteettisen ja henkilökohtaisen kuin poliittisen ja julkisen kautta. Adornon sodanjälkeisen ajattelun eettinen ydin oli lisäksi vaikeasti yhteensovitettavissa radikalisoituvan opiskelijaliikkeen vaatimusten kanssa, sillä se perustui olemukseltaan pikemminkin kiellolle kuin affirmatiolle. Adornon Negative Dialektikissa (1966) esittämän ajatuksen mukaan Hitlerin ihmisille pakottama uusi kategorinen imperatiivi käskee suuntaamaan toimintansa niin, ettei mitään Auschwitzin tapaista enää koskaan tapahdu. Adornon perspektiivi oli olennaisesti katastrofin uusiutumisen ehkäisemisessä ja siten hän tarkasteli yhteiskunnallista emansipaatiota pikemminkin sen välttämättömien reunaehtojen kuin sen toteuttamiseen johtavien toimien kautta.

Tämä orastava erimielisyys on nähtävä taustana Adornon ja opiskelijaliikkeen riitaantumiseen vuonna 1969. Siihen saakka opiskelijaliike oli pitänyt Adornoa oppi-isänä, joka kriittisen teorian ensimmäisen sukupolven ajatteli- joista oli näkyvimmin esillä saksalaisessa mediassa. Adorno kirjoitti, debatoi ja opetti itselleen tunnusomaisella yhdistelmällä liki hurmoshenkistä tarmoa ja hienovaraista tilannetajua. Tämän lisäksi hän, toisin kuin Max Horkheimer tai Herbert Marcuse, oli konkreettisesti tapahtumien keskipisteessä Frankfurtissa. Opiskelijaliikkeen vahvistuminen vuosina 1967-1969 johti kuitenkin tilanteeseen, jossa Adorno koki voimiensa kuluvan välittäjän roolissa opiskelijoiden ja yliopistohallinnon välissä. Aika ja energia, joita kirjoittamiseen olisi tarvittu, oli varattava opiskelijoille. Lisäksi Adornoa rasitti opiskelijoiden tapa keskeyttää luennot pikemminkin muodon vuoksi kuin spontaanisti, ja vuoden 1969 alussa Adorno koki liikkeen yrittävän manipuloida itseään ja käyttää hänen vaikutusvaltaansa poliittisesti räjähdysalttiiden näkemystensä levittämiseen. Vallankumousjohtajan roolista kirjoituksessaan "Marginalien zur Theorie und Praxis" kieltäytynyt Adorno joutui opiskelijoidensa nolaamaksi luennollaan ja kutsui sekavien vaiheiden jälkeen poliisin tyhjentämään yliopiston hallintorakennuksen. Mitä ilmeisimmin Adorno todella koki väkivallan uhkaavan itseään, mutta poliittisesti polarisoituneessa tilanteessa seuraukset olivat armottomat. Adornon aiemmin yhteistyöllään hankkima arvostus tippui ropisten liikkeen silmissä. Symbolisesti virkavallan kanssa liittoutuneen Adornon ajattelua tahrasi nyt vasemmisto-opiskelijoiden silmissä epäilys, ettei se todellisuudessa ollutkaan vallankumouksen puolella, vaan salaa hyväksyi auktoriteettien harjoittaman väkivallan. Adornon maksiimi Auschwitzista on syytä muistaa ja verrata sitä aikansa konservatiivisiin ja radikaaleihin näkemyksiin, jotka myös hakivat oikeutusta mielipiteilleen Saksan natsimenneisyydestä. Iltapäivälehti Bild kirjoitti opiskelijoihin viitaten, etteivät saksalaiset halua kaduille "ruskeaa tai punaista SA:ta". Kenties todellisuudentajuisempi mutta samalla synkästi kohtalokas oli RAF:n perustajajäsenen Gudrun Ensslinin kommentti, jonka mukaan "Auschwitzin rakentajien kanssa ei voi neuvotella [...] Meidän on aseistauduttava”. Kevätlukukausi 1969 päättyi kriittisen teorian ja opiskelijaliikkeen välirikon tunnelmiin. Elokuussa ylirasittunut Adorno kuoli yllättäen sydänkohtaukseen lomallaan. Kohtaus iski Sveitsissä lähellä Vispiä, kun hän vastoin lääkärinsä varoitusta yritti kiivetä Matterhornin juurella kohoavan pienemmän vuoren huipulle.

Peter Uwe Hohendahl on todennut Ästhetische Theorien julkaisusta vuonna 1970, että kirjan vastaanotto oli hämmentävän torjuva. Vaikka teosta oikeutetustikin pidettiin kriittisen teorian perintönä, oli tästä määreestä tullut stigma poliittisesti muuttuneessa tilanteessa. Kirjan DDR:ssä saama tuomio dialektisen materialismin opinkappaleiden valossa oli odotettu, mutta sen negatiivinen vastaanotto länsisaksalaisen opiskelijaliikkeen piirissä aiheutti trauman, jota ei itse asiassa ole vieläkään hoidettu. Etupäässä marxilaisleninistisesti asennoitunut opiskelijaliike oli odottanut kriittisen teorian johtoääneltä materialistista taiteenteoriaa, eikä kirja vastannut sen toiveita. Tämä huomio tehtiin tilanteessa, missä opiskelijaliike kävi läpi suuria muutoksia. Sen suuri näkyvyys 1960-lu- 
vun lopulla ei ollut johtanut poliittisen vaikutusvallan kasvuun, ja keskinäisten riitojen tunnelmissa liike oli hajaantumassa. Vuonna 1970 liike oli astumassa uuteen vaiheeseen, joka merkitsi aiemman, pitkälti Frankfurtin koulukunnan inspiroiman teorian hylkäämistä. Yhtäältä kommunistinen puolue tarjosi liikkeelle väylää politiikkaan, mutta tämä edellytti Adornon kritiikkiä ja spontaanisuutta painottavan ajattelun korvaamista Leninin ja Trotskin systemaattisemmilla vallankumousteorioilla. Puoluepoliittisesti suuntautuneelle vasemmistolle Adorno näyttäytyi liberaalina kulttuuriporvarina, joka ei ollut valmis tinkimään subjektin porvarillisista vapauksista joukkoliikkeen hyväksi. Tätä erkaantumista voi pitää molemminpuolisena ja peruuttamattomana: näkökulmat olivat liian etäällä toisistaan. Esteettisessä teoriassa Adorno ilmaisee selvästi haluttomuutensa valjastaa taiteen ja ajattelun kriittiset voimat ennalta-annettujen poliittisten päämäärien palvelukseen.

Toinen etääntyminen oli kivuliaampi. Radikaali alternative-kirjallisuuslehti oli vuoden 1967 Walter Benjamin numerossaan nostanut esiin kysymyksen Adornon vaikutuksesta Benjaminiin tämän eläessä ja Benjaminin kirjoitusten käsittelyyn tämän kuoleman jälkeen. alternativen raskaimmat väitteet koskivat Pariisissa sodan uhan alla työskennelleen Benjaminin taloudellista riippuvuutta New Yorkiin emigroituneesta Institut für Sozialforschungista: Adornon ja Horkheimerin annettiin ymmärtää ohjailleen Benjaminia ja kiristäneen häntä taloudellisella tuellaan. Henkilökohtaiset ja teoreettiset kysymykset sekoittuivat mo- nimutkaiseksi vyyhdeksi, jonka lopputulema oli poliittisesti latautunut: alternativelle Benjamin oli materialistisen taideteorian sankari ja marttyyri, Adorno puolestaan sen vesittäjä. Adorno ei kieltänyt sitä, mikä tähän mennessä oli muutenkin jo selvää, nimittäin että hän oli 1930-luvulla päätynyt puolustamaan Benjaminin aiempaa metafyysistä filosofiaa tämän ajattelun uudempaa, poliittisesti sitoutunutta käännettä vastaan. Adornon Benjaminille kirjoittamien kirjeiden kieltämättä mestaroiva sävy selittyy pyrkimyksestä puolustaa häntä Bertolt Brechtin suoraviivaiselta marxismilta. Adorno katsoi molempien olleen Marxin lukijoina epäkriittisiä ellei peräti pinnallisia, ja erityisesti Benjaminin käännettä marxismiin hän piti "pillerin nielemisenä". Tämän monimutkaisen suhteen selvittäminen tapahtui ennen kaikkea Esteettisessä teoriassa. Kirjan lukijat saivat pian huomata, ettei Adorno ollut muuttanut avantgardea suosivaa ja populaarikulttuuria väheksyvää kantaansa yhtään sen enempää kuin hän oli antanut poliittisesti sitoutuneen opiskelijaliikkeen kääntää päätään yksilöllisen suosimisesta kollektiivin suuntaan. Kysymyksen polttopisteeksi nousi kysymys autonomisesta taideteoksesta, jonka puolustuksena Esteettistä teoriaa aivan oikein luettiin, ja minkä tähden se myös ilmestymisensä aikoihin tuomittiin.

II

Esteettinen teoria on Adornon taiteen ajattelun summa paitsi kohtalon oikusta, myös ilmeisen tarkoituksellisesti. Suomennetun teoksen yli 500 sivun mittaan Adorno tuo esiin suuren osan 40 vuoden aikana käsittelemistään taidekysymyksistä. (Suomennoksesta on jäänyt puuttumaan satakunta sivua teoksen keskeneräisintä materiaalia, nimittäin "Paralipomena"-nimikkeen alle kootut huomiot, jotka Adornon oli tarkoitus liittää pidemmälle työstettyyn kirjan pääosioon. Lisäksi pois on harmittavasti jäänyt kiinnostava ekskursio taiteen alkuperää koskeviin teorioihin.) Taiteenlajeista nousee erityisesti esille Adornon suuri rakkaus, länsimainen taidemusiikki, ja vaikka hänen suhteensa modernin musiikin suureen kapinalliseen, Arnold Schönbergiin, oli vuosien myötä jäähtynyt, säilyttää Schönbergin atonaalinen musiikki yhä vahvan analogian efektiin, jota Adornon kirjoitus tavoittelee: dissonanssin ilmiö totuutena, jonka harmonian rikkominen paljastaa. Tämä näkökulma kiinnittyy oleellisesti varhaisromantiikasta periytyvään asenteeseen, johon Adornon kirjoitus oli aina suhtautunut ambivalentisti. Tietty romanttinen ja paatoksellinen ele, joka Adornon tekstissä on, ilmenee tyylipuhtaimmin pidäkkeiden ja patoamisien kautta. Itsekin nuoruudessaan vakavasti säveltäjän uraa kaavaillut Adorno päätyi filosofian ja kritiikin pariin pysyvästi jo 1920-luvulla. Esteettisen teorian filosofiset auktoriteetit löytyivätkin Adornon kirjahyllystä jo tuolloin. Hegel, Marx, Nietzsche, Freud, Lukács - Adornon taidefilosofian teoreettinen perusta on järeää, saksalaista laatua. Kant jää mainitsematta tässä vain siksi, että Puhtaan järjen kritiikkiin Adorno oli tutustunut jo 15-vuotiaana, siis 1910-luvulla.

Kirjan varsinaiseksi esikuvaksi ja ainoaksi todelliseksi 
kiistakumppaniksi voi kuitenkin kutsua vain Benjaminia. Adorno kelpuuttaa ainoastaan Benjamin vertaisekseen yrittäessään hahmottaa moderniteetin, yhteiskunnan, taideteoksen ja filosofisen esityksen yhteyttä. Samalla näyttää siltä, että Esteettisen teorian kohdalla Adorno on todella pistänyt kaikkensa peliin luodakseen monumentaalisen teoksen modernista ja samalla modernistisen teoksen, eräänlaisen Gesamtkunstwerkin, joka samalla kyseenalaistaa tämän kategorian historiallisen mahdollisuuden myöhäiskapitalismin ajalla. On syytä tarkentaa kysymystä. Kirjan syntyhistoriasta tiedetään, että vaikka Adorno tuotti näennäisen helposti suuren määrän tekstiä kirjaa varten, tuotti tekstikatkelmien järjestäminen hänelle suuria ongelmia. Hän ei ollut tyytyväinen raakatekstiin pitkällisen työstämisen jälkeenkään, ja syksyllä 1968 hän luopui ajatuksestaan jakaa kirja luvuiksi - tätä ennen oli hylätty alkuperäinen suunnitelma kirjan jäsentämisestä kappaleiksi. Adornon toinen kriittinen luenta käsikirjoituksesta tuotti kuvailevien aihenimien alle hahmotellun tekstin, jossa argumentatiivisen tai hierarkkisen rakenteen sijaan samat kysymykset ja vastakkainasettelut toistuvat ikään kuin jatkuvana variaatioiden sarjana. Adorno kuvaili kirjan muodonantoon liittyviä ongelmia yksityisessä kirjeessä vuonna 1969 näin:

"On kiinnostavaa, että työni ajatusten sisällöstä juontuu muotoa koskevia seurauksia, joita olin tosin osannut odottaakin, mutta jotka kuitenkin nyt hämmästyttävät minua. Kyse on yksinkertaisesti siitä, ettei teoreemani mukaan filosofisesti 'ensimmäistä' ole, ja tästä seuraa, ettei argumentatiivista yhteyttä voi rakentaa tavanomaisen asteittaisen kulun mukaisesti, vaan kokonaisuus on rakennettava osakokonaisuuksien sarjoista. Nämä ovat ikään kuin samanpainoisia ja vaiheina samankeskisiksi järjestettyjä joka askeleella; niiden konstellaation, ei niiden seuraannon, tulee ilmaista idea." (ET, 561562. Suomennosta muutettu.)

Sarja osakokonaisuuksia, jotka on järjestetty samankeskisiksi ja joiden konstellaatio ilmaisee idean - mitä Adorno tarkoittaa? Termi konstellaatio on merkittävässä osassa myös Adornon filosofisessa pääteoksessa Negative Dialektik, jossa filosofista ajattelua luonnehditaan konstellatiiviseksi. Tämä tarkoittaa pyrkimystä ajatella ajattelua tarkastelukulmasta riippuvaisten hahmojen kehittelynä. Näin filosofinen ajattelu ei pyrkisi muodostamaan käsitehierarkiaa, jossa osat palvelevat kokonaisuutta ja yksittäiset väitteet argumenttia. Pikemminkin filosofinen ajattelu tulisi nähdä jännitekentän hahmotteluna, jossa kontrastoivat positiot virittyvät toisiaan vasten ja eri näkökulmista luonnostellut kuviot muodostavat päällekkäisinä ja toisistaan eroavina eräänlaisen käänteiskuvan siitä, minkä tällainen ajattelu hyväksyy itselleen saavuttamattomaksi eli kokonaisuudesta. Hahmopsykologiasta tutun pupuankkakuvan mukaan voisimme ajatella Adornon filosofista päämäärää eräänlaisten päällekkäiskuvioiden muotoilemisena. Analogiaa pupuankka-kuvan ja konstellatiivisen ajattelun välillä voi lähestyä myös niiden jakaman negativiteetin kautta: molemmissa tapauksissa hahmoon sisältyy enemmän kuin siitä yhtenä ajanhetkenä tehtyyn tulkintaan, ja tämän osoittaa siirtymä tulkintojen välillä. Siirtymä tulee havainnon piiriin ainoastaan erona, joka nakertaa luottamusta yksittäiseen tulkintaan. Adornon ajatus on että toimiva konstellaatio ei sulata yksittäisiä hahmojaan korkeamman tason kokonaisuuteen eikä hahmojen välillä vallitse myöskään ristiriitaa. Tällä ajatuksella on yhteytensä Benjaminin saksalaista barokkidraamaa käsittelevän kirjan Ursprung des deutschen Trauerspiels teoriaan allegoriasta, mutta aivan erityinen kaltaisuus sillä on Benjaminin keskeneräiseksi jääneeseen Passagenwerkiin, teokseen, jonka parissa hän työskenteli vuodesta 1927 alkaen aina kuolemaansa saakka vuonna 1940. Benjaminin päämääränä oli modernin kokemusmuodon materiaalisen esihistorian esitys ja fysiognomia 1800-luvun Pariisista, pelkkään arkistomateriaaliin nojaava kirja sitaattimuodossa. Passagenwerkja Esteettinen teoria muistuttavat toisiaan paitsi keskeneräisyytensä, myös radikaalin konstruktioperiaatteensa puolesta. 1960-luvulla innostus Benjaminista esteettis-poliittisena ajattelijana ei kuitenkaan kiinnittänyt niinkään huomiota hänen varhaisiin teksteihinsä ja vielä julkaisemattomaan Passagenwerkiin, vaan 1930-luvun poliittisiin teksteihin, ja erityisesti näille teksteille Adorno etsii Esteettisessä teoriassa vastausta, 30 vuotta Benjaminin kanssa käymänsä mielipiteenvaihdon jälkeen. Erityisesti "Taideteos teknisen uusinnettavuutensa aikakaudella", kenties Benjaminin tunnetuin yksittäinen teksti, on ehtymätön voimanlähde Esteettiselle teorialle. 
III

"Taideteos"-esseessään vuodelta 1936 Benjamin esittää tiiviin historiallisen hahmotelman taiteen kehityksestä sen monistamisen näkökulmasta. Taiteen tekeminen on hänen mukaansa palvellut ensimmäisenä rituaaleja, jolloin taideobjektille on kuulunut siihen sidonnainen kulttiarvo. Vaikka termin "taideteos" käyttäminen onkin kulttiarvon puitteissa tarkkaan ottaen anakronistista, juontuu taideteoksen käsite historiallisesti tästä alkuperästä. Olennaista kulttiarvolle on taideobjektin korvaamattomuus maagisten voimien tyyssijana sekä sen kanavoimien yliluonnollisten voimien sosiaalinen säätely objektin esilläolon rajoittamisena. Erotuksena käsitöistä ja muista arkeen liittyvistä askareista on taideteoksen käsitteen alkuperä Benjaminille sen ritualistis-maagisessa käytössä. Tämän käytön kontrolli tekee taideobjektista "niukan hyödykkeen": sen olemukseen kuuluu, ettei se ole yleisesti kaikkien saatavilla jatkuvasti. Uskonnolliset kuvat ja veistokset ovat kulttiarvon historiallisesti myöhempi ilmentymä, ja myös uuden ajan maalaustaidetta voidaan ajatella tältä perustalta. Keskeistä taide-esineille on tässä katsannossa niiden ainutkertaisuus, niiden taiteelliseen identiteettiin kuuluu piirre, jota Benjamin kuvaa niiden olemiseksi "tässä ja nyt" (Hier und Jetzt). Tätä Benjamin kutsuu teoksen auraksi. Myöhemmin taidekauppa hyödyntää auraa taide-esineen aitouden kriteerinä, sillä aura koskee myös esineen identiteettiä ajassa. Benjaminin hahmotelman marxilainen kärki on tuotantovoimia koskeva huomio, jonka mukaan vallit- sevissa teknisen kehityksen olosuhteissa ei ole perusteita ajatella taiteen tuotantoa sellaisen mallin kautta, jossa yksittäisellä "aidolla" teoksella on oma ainutkertainen auransa ja sijaintinsa. Teknisen uusinnettavuuden aikakauteen sisältyy potentiaali vapauttaa taideteos "loismaisesta rituaalisidonnaisuudesta", luoda uusia käytäntöjä ja havaitsemistapoja. Benjamin ajattelee ennen kaikkea valokuvaa ja elokuvaa uusinnettavuudelle perustuvina taidemuotoina sekä sellaisia teknisiä ratkaisuja kuin montaasia ja hidastusta keinoina tuottaa uusia havaitsemisen tapoja. Lisäksi kehitys mahdollistaa taiteen poliittisen merkityksen kasvun, sillä harvojen ja valittujen sijaan taideteos on nyt potentiaalisesti kaikkien saatavilla. Massat eivät vaadi taiteelta ainutkertaisuutta ja etäisyyden kokemusta, jotka kuuluvat auraattiselle taideteokselle ja joita eliitti on aina arvostanut. Joukot hyväksyvät jäljennöksen ja tahtovat voittaa ainutkertaisuuden: tarpeellinen on tuotava lähelle.

Adornon vastustus Benjaminin teoriaa kohtaan Esteettisessä teoriassa on peräisin syvälle käyvästä hahmotustapojen erosta, johon kiinnostavasti liittyy merkittävää vaaliheimolaisuutta toisissa kohdin. Yksi Adornon ja Benjaminin ajattelua yhdistävä tekijä voidaan nähdäkseni löytää Nietzscheltä. Kyseessä on genealoginen, polveutumista painottava tapa ajatella alkuperää, joka ilmenee Benjaminin ajatuksessa, etteivät taiteen historiallisesti ensisijaisiin arvoihin kuulu estetiikan tradition myöhäistulokkaat, kauneus ja harmonia. Benjaminille taiteen alkuperäinen päämäärä löytyy pikemminkin rituaalisesta kommunikaatiosta jumalallisen tai kosmisen kanssa. Adorno seuraa tässä ajattelun suuntaamista koskevassa kysymyksessä Nietzscheä ja Benjaminia aina 1930-luvun alun kirjoituksistaan lähtien. Hänen yhdessä Max Horkheimerin kanssa kirjoittamassaan Valistuksen dialektiikassa (1944/47) muotoillaan ajatus taiteen kehityksestä historiallisena sedimentoitumisena, jonka moninaiset alkuperät voivat ajan kulussa painua näkyvistä. Lisäksi Adorno painottaa modernissa tilanteessa taiteen olevan väistämättä oman alkuperänsä kritiikkiä, niin että taiteen tekeminen muodonantona on nähtävä tradition tarjoaman materiaalin kriittisenä muokkaamisena. Benjaminin esseen hengessä Adorno näkee tämän tapahtuvan integroimalla uusia tekniikoita estetiikan ulkopuolelta. Taide osallistuu näin valistuksen projektiin ollessaan kriittinen ja jopa tuhoava omaa traditiotaan kohtaan, johon sen kuitenkin samalla on kytkeydyttävä: tätä on "modernin murhaava historiallinen voima" (ET, 88). Tähän ajatukseen sisältyy näkemys tekniikasta itseään vastaan kääntyvänä väkivaltana, missä suhteessa Adorno ajattelee kuitenkin selkeästi taideimmanentimmin kuin Benjamin. Pitkälti "Taideteos"-esseen linjoilla Adorno kuitenkin kirjoittaa Esteettisen teorian suomennokseen sisältymättömässä ekskursiossa "Taiteen alkuperän teorioista", että koska taide on historiallinen prosessi, ei sen muinaisista alkuperistä löydy päämäärää, jota voitaisiin enää ymmärtää. Genealogiassaan Adorno kuitenkin suosii selkeästi rumaa ja arkaaista taiteen mahdollisena alkuperänä: "kauneus on syntynyt pikemmin- 
kin rumasta kuin päinvastoin" (ET, 117).

Antropologinen näkemys ruman ja hirvittävän herättämisestä ja hallinnasta rituaalin avulla on Adornolle läheisempi kuin durkheimilainen ajatus yhteisöstä palvomassa itseään omassa kuvassaan. Kuva on pikemminkin vieras, mutta välttämätön. Ennen kaikkea Adorno kritisoi klassisistisen taideteorian ideaaleja, kauneutta, harmoniaa ja tasapainoa, mikä johtaa hänet käänteisesti hakemaan taiteen alkuperää klassisismin ideoiden kääntöpuolelta: "Taide ei pysy kauhulle uskollisena kääntämällä sille selkänsä. Taide on pikemminkin kauhun perintöä.” (ET, 239.) Eräänlaisena freudilaisena motiivina tässä ilmenee torjutun paluu ja kaksoissiteen logiikka: taiteen yhteys rituaaliin merkitsee, että se kantaa muassaan rituaalin funktiota ja esittää rajatusti sen, minkä yhteisö on karkottanut vaarallisena. Yhteyden rituaaliseen säilyttävä moderni taide ikään kuin manaa pois omaa traditiotaan, mutta keinot tähän se saa vain tältä traditiolta. Kriittisesti Adorno katsookin "ruman" olevan klassistisen estetiikan ja naiivin ajattelun antama nimi sille, mikä modernissa paljastuu dissonanssiksi. Koska musiikista tiedetään, että dissonanssia voidaan ajatella ainoastaan konsonanssin ja harmonian käsitteiden kautta, liikutaan selvästi alueelle, jolle Adornon ja Benjaminin kiista auran tuhoamisesta varsinaisesti sijoittuu.

Kiteyttäen Adorno ei suostu luopumaan taiteen auraattisuudesta ja etäisyyden kokemuksesta. Adornon ja Benjaminin kirjoituksia vertailemalla voidaan havaita, että he tuntuvat ajattelevan eri taidemuotoja. Benjaminille au- ran purkamisen itseoikeutettu taidemuoto on elokuva, kun taas Adorno ajattelee ennen kaikkea musiikkia. Lisäksi Benjamin kuvaa modernia elokuvayleisöä hajamieliseksi kollektiiviksi, mikä viittaa taiteen vastaanoton ajattelemiseen pikemminkin ruumiillisena läsnäolona ja toimintakykynä kuin henkisenä suorituksena. Tässä suhteessa Adorno vaikuttaa perinteisemmältä, sillä hänelle taidekokemuksessa on etupäässä kyse hengen aktiviteetista, minkä puitteissa pätevä ja epäpätevä tulkinta erotetaan toisistaan. Hänelle taideteos on arvoitus, johon ei kylläkään sisälly ratkaisua, mutta tämän arvoituksen ymmärtäminen vaatii vastaanottajalta osaavaa toimintaa. Kysymys tarkentuu koskemaan sosiaalisuuden ja esineellisyyden hahmotuseroja Adornolla ja Benjaminilla.

Benjamin katsoo taiteen versoneen ennen kaikkea jäljittelevistä käytännöistä, jotka ikään kuin tiivistävät itseensä jotain oleellista yhteisöelämän kokonaisuudesta (ks. "Mimeettisestä kyvystä"). Erityisesti uusinnettavuus-teesille ominaista taas on taiteen ajatteleminen esineiden kautta, ja tämän näkemyksen hän ilmaisee fragmentissa "Unikitschiä": "Se, mitä sanomme taiteeksi, alkaa vasta kahden metrin päässä ruumiista." Adornolle tyypillistä on puolestaan ajatella taidekokemusta sen vaikutuksesta käsin, etenkin somaattista vaikutusta, jonka herättäjänä hän useinkin mainitsee kauhun, vaikka myös seksuaalinen sokki figuroi usein hänen kirjoituksissaan. Adorno painottaa tyypillisesti kokemusta, jonka vaikutuspiiri on yksityinen ja joka sisältää immateriaalisen juonteen. Jo vuonna 1928 kirjoittamassaan katkelmassa hän panee merkille, että porvarillisista kaunotaiteista omistamisen paradigma ei sovellu musiikkiin. Vaikka samaa voitaisiin sanoa vaikkapa arkkitehtuurista - ja Benjamin käyttääkin sitä esimerkkinään - ei sen julkinen ja arkinen sävy sovellu Adornon hakeman taidekokemuksen malliksi. Partituurit ja piano sekä myöhemmin levysoitin saattavat hyvinkin kuulua porvarilliseen interiööriin, mutta musiikin kokeminen on Adornolla sidottu konserttikäytäntöön, joka taidetapahtumien joukossa nimenomaan yhdistää aineettoman (ei empiiristä taideobjektia) ja henkisen. Sosiaalisesti taidemusiikkitapahtumaa taas voi pitää modernina rituaalina, johon keräännytään olemaan kollektiivisesti yksin. Elokuva, Benjaminin esimerkki modernista taidetuotannosta, muistuttaa konserttia tapahtumana, mutta myös eroaa siitä. Sillä kun elokuva on todellakin jotakin materiaalista ja kopioitavaa, selluloidia kelalla, perustuu musiikkiesitys olemassaolevan teoksen tulkintaan. Tästä painotuserosta käsin voidaan alkaa hahmotella sitä, mikä Adornolle taidekokemuksessa on positiivisessa mielessä auraattista ja miksi hänen versionsa kriittisestä teoriasta muotoutui siksi, mitä se lopulta sanookin olevansa: esteettiseksi teoriaksi.

\section{IV}

Esteettinen teoria painottaa esteettistä kokemusta tavalla, joka voi näyttää varsin perinteiseltä estetiikan traditiossa. Voitaisiin esimerkiksi kysyä juuri esitetyn skeeman sukulaisuutta Kantin Arvostelukyvyn kritiikissä esittämälle klassiselle jäsennykselle. Kantille 
esteettinen arvostelma koskee subjektin aistimellisuuden tuottamaa synteesiä siitä, mikä pakenee käsitteelliseltä tiedolta, mutta samalla tuo läsnäolevaksi sen perustan, jolle käsitteellinenkin synteesi perustuu. Näin tieto ja tunne rakentavat siltaa toisiaan kohden ja niiden uumoiltu yhdistyminen takaa filosofisen totuuden mahdollisuuden. Adornon sympatia antiklassisistista (modernia, dissonanttista) teosta kohtaan näyttäisi tosin painottuvan etupäässä kantilaisittain ylevän kokemuksen puolelle, joka viittaa mielen kykyjen ristiriitaan ja jumiutumiseen. Kantin ylevän negatiivisuutta vastaan tosin asettuu Adornolla esteettisen kokemuksen tekninen momentti, teoksen ja sen esityksen tulkitseminen oikein. Kantin arkkitehtuurissa tämä painotus johtaisi ennemminkin tiedollisen kuin esteettisen arvostelman piiriin, Adorno taas niveltää näitä vaikutuspiirejä yhteen, samastamatta niitä kuitenkaan toisiinsa. Näissä huomioissa nousee esiin se, että alkuperän ajattelua kohtaan esittämästään kritiikistä huolimatta Adorno näyttää kohtaavan ainakin modernin taiteen laajassa mielessä formalistisesti: hän lähestyy sitä tekniikkaa ja yksityistä kokemusta painottavan arkkityypin perusteella ja rajoittaa tämän tyypin esiintymät lähinnä korkeakulttuuriin. Nähdäkseni tulkinta Adornosta "modernismin kantilaisena" ei kuitenkaan tavoita hänen teoriansa omaperäisimpiä juonteita, joita yritän seuraavaksi selvittää lumeen, autonomian ja mimesiksen käsitteiden avulla.

Adornon hyökkäys kulttuuriteollisuutta vastaan tunnetaan laajasti. Kyseessä on yksi 1900-luvun ehdottomim- mista protesteista yhteiskunnallista kehitystä kohtaan, joka niveltää taiteen osaksi tuottavaa yhteiskuntaa ja "väsyneen bisnesmiehen" työkyvyn palauttavaksi ajanvietteeksi. Harvoin on kolmeen kirjaimeen mahtunut yhtä paljon ylenkatsetta kuin Adornon lainatessa englannista termin yhteiskunnan taiteettomaksitulemisen kuvaamiseen: nyt taiteenkin on oltava fun. Marxilainen painotus on huomattava. Kulttuuriteollisuus on Adornolle riistoa sanan perustavimmassa mielessä, sillä se pyrkii anastamaan sen, mikä on ihmiselle ominta: aistimiseen ja ajatteluun sisältyvän muutoksen mahdollisuuden. Tämä on Adornon taidefilosofian tunnetuin anti yhteiskuntakritiikille. Valistuksen dialektiikassa kysymys kulttuuriteollisuudesta avaa huolestuttavan näkymän liberaalin yhteiskunnan taipumukseen ravita kansalaisiaan mieluummin standardoiduilla kulttuurituotteilla kuin esteettisillä kokemuksilla. Ensin mainittuihin pätee vaihdon logiikka, kun taas jälkimmäistä luonnehtii Adornolla ambivalentti lumoutumisen ja häirityksi tulemisen kokemus. Kulttuuriteollisuus siis passivoi, kun se tekee kulttuurista tuoteselosteen mukaisia tuotteita. Autonominen teos näyttää puolestaan jollain tavalla samanaikaisesti lumoavan ja riivaavan. Kulttuuriteollisuuden autonomian riisto ja autonomisen teoksen ambivalentti monimielisyys tuntuvat kytkeytyvän toisiinsa. Mikä logiikka näitä autonomian hahmoja yhdistää?

Kiinnostavassa katkelmassa Adorno nostaa ilotulituksen taideteoksen esikuvaksi (ET 172-173). Painotus ei nyt koske tekniikkaa ja vastaanottoa vaan taiteen ilmenemis- tä. Adornolle taideteokset, jotka "lahjomattomasti kieltäytyvät juhlista ja lohdutuksesta" - siis hänen suosimansa muoto-kieleltään ankarat ja traditiotaan vastaan kääntyvät teokset - "eivät lakkaa säteilemästä, ja mitä onnistuneempia ne ovat, sitä enemmän ne tuota voimaa saavat". (ET 174. Suomennosta muutettu.) Tässä Adorno ilmaisee itse asiassa sen, että onnistunut moderni taideteos tuo teknisen ja kriittisen ilmiasunsa kautta esiin jotakin, mikä määrittelee myös taiteen arkaaista esihistoriaa. Kyse on eräänlaisesta ympärikääntymisestä, jonka nimittäminen dialektiseksi voisi olla ennenaikaista. Onnistuneessa teoksessa Adorno katsoo tapahtuvan jotakin, mitä hän kutsuu lumeeksi (Schein): se on loiston ja valon ilmenemistä, mutta myös näkymä jostain epätodellisesta, illuusio. Lumeen ilmenemisellä on yhteys manaan ja magiaan, mutta aivan erityisessä mielessä. Kulttuuriteollisuuden halpaa pintakiiltoa Adorno vertaa sokaistumiseen ja turruttavaan humaltumiseen (minkä markkinoinnista "taianomaisena" hän on erittäin tietoinen), kun taas autenttisen taideteoksen lumeen tekee mahdolliseksi siihen sisältyvä raitistava tekniikka, joka sitoo sen traditioon. Adornon puolustamassa autenttisessa teoksessa toimintaan asettuukin kaksi lähtökohtaisesti toisilleen vierasta periaatetta, lume ja kritiikki. Nämä astuvat suhteeseen, jonka selittämiseksi on otettava askel taaksepäin ja tarkasteltava Valistuksen dialektiikassa esitettyä teoriaa mimesiksestä. Positiivinen tulkinta lumeesta perustuu oleellisesti Adornon poikkeukselliseen ajatukseen mimesiksestä. 
Valistuksen dialektiikassa Adorno ja Horkheimer esittävät myytin ja valistuksen toisiaan vastaan kääntyvien, mutta samaa luonnonhallinnan projektia toteuttavien hahmojen yhteiseksi perustaksi niiden mimeettisen kantasiteen. Mimesistä ei tässä hahmotuksessa tulkita jäljittelyksi, kuten taideteorian perinteessä on yleensä tehty, vaan perustavammaksi esisubjektiiviseksi siteeksi, joka edeltää yksilöitymisperiaatetta. Mimesistä kuvaillaan paitsi lapsuudessa vaikuttavaksi välittömän mukautumisen tilaksi, myös elollisessa luonnossa yleisesti vaikuttavaksi voimaksi, joka liittää yksilön ympäristöönsä. Mimeettiset toiminnot ovat Adornon ja Horkheimerin mukaan tyypillisesti ei-tahdonalaisia, kuten suojavärimekanismi tai vaaran välttäminen kuolleeksi tekeytymällä. Tässä suhteessa mimesis on oleellisesti passiivinen ja tiedostamaton kyky, jota voisi kutsua myötämuuttumiseksi. Luonnonhallinta, jonka Valistuksen dialektiikka katsoo sekä myyttistä selittämistä että valistuksen käsitteellistä kontrollia ajavaksi voimaksi, on eräänlaista mimesiksen haltuunoton yritystä, joka kuitenkin epäonnistuu väistämättä, koska mimesis on hahmotettu ulkoisen ja sisäisen suhteeksi, eikä siitä siten voi tulla yksilön teknisen hallinnan tai käsitteellisen tiedon kohde. Monien 1900-luvun filosofisten hahmotusten tapaan mimesistä katsotaan tässä eräänlaisen rakenteellisen mahdottomuuden linssin lävitse: sen hallitsemisen pyrkimys on luonnonhallintaa ajava moottori, mutta samalla jotakin hallinnan ulkopuolelle jäävää, koska tämän hallinnan subjekti esitetään kirjassa tulokseksi mimesiksen särky- misestä, ulko- ja sisäpuolen välisen eron syntymisestä. Tästä eteenpäin mimesis on Adornon mukaan tabu: kielletty, houkutteleva ja vaarallinen. Valistuksen dialektiikassa mimesiksen ilmiasuja ovatkin subjektin synnyn jälkeen väkivaltaiset ja seksuaaliset passiot, sekä näitä palveleva projisoiva ajattelu. Eräänlaisena luonnon kostona mimesiksen kiellon hahmotetaan kirjassa johtavan väkivaltaiseen syöveriin, joka lopulta nielee kantajakseen asettamansa subjektin, kun sen pyrkimykset käsitteellisiin erotteluihin raukeavat. Voi huomata jälleen rituaalin logiikan: se, mikä on hallitsemattomana suljettu ulos, olisi hallinnan näkökulmasta voitava tuoda takaisin muuttuneessa muodossa, myrkystä lääkkeeksi jalostuneena. Valistuksen dialektiikka on kuitenkin erittäin skeptinen mimesiksen kollektiivisten hallintatekniikoiden toimivuuden suhteen. Ne yhdistetään etenkin uhraamiseen, jonka Adorno ja Horkheimer katsovat pikemminkin saastuttavan kuin puhdistavan yhteisön kokonaisuudessaan.

Esteettinen teoria lisää tähän hahmotukseen tärkeän piirron, joka tuo mimesiksen ja toiminnan yhteen taiteessa: "Taide on mimeettisen toiminnan turvapaikka. Subjekti paljastaa siinä itsensä, autonomian eri asteillaan, sille, mikä on sen suhteen toista, siitä erillistä eikä kuitenkaan täysin erotettua." (ET, 122.) Mimeettinen toiminta on nähtävä aktiivisen toiminnan ja passiivisen mimesiksen harvinaisena liittona. Adornon sävy on myönteinen, sillä taiteen teknisessä menettelyssä mimesis ikään kuin puhdistuu subjektin passioista. Se yhdistyy luonnonhallinnan subjektin päämääristä vapautet- tuihin toimintoihin, jotka saavuttavat esteettisen rationaalisuuden.

Mutta palautuuko mimeettisen positiivinen painottuminen taiteessa Adornon korostamaan taidekokemuksen privaattiin luonteeseen? Näyttäisi siltä, että hegeliläinen näkemys subjektin toiminnasta eräänlaisena objektin nihilointina toimii Adornolla sekä subjektikritiikin että sen korjauksen perspektiivinä. Ensinnäkin mimeettisen kieltävä ja sitä hallitsemaan pyrkivä subjekti suuntautuu objekteihin niiden hyödyntämismielessä, kuten Valistuksen dialektiikassa esitetään. Koska subjektin suhde objektiin on kuitenkin Hegelille ja häntä tässä seuraavalle Adornolle myös suhde itseen, suuntautuu subjekti itseensäkin hallinnoivana ja hyödyntävänä. Tässä itseen palaamisen liikkeessä kielletty mimesis ottaa vallan ja uhkaa subjektia ja objektia niiden eron kuluttavalla elementaarisella ykseydellä. Toiseksi Adornon hahmotelma subjektille avoimeksi jäävästä esteettisestä korjausliikkeestä lähtee liikkeelle ajatuksesta, että suhteen on käännyttävä, jotta se voisi muuttua: objektin on tavallaan lamaannutettava subjektin hallinta. Juuri tähän taiteen lume ja sen riivaava vaikutus perustuvat, sillä esteettisessä kokemuksessa objekti ikään kuin ottaa vallan ja nihiloi subjektin. Taiteen ele on Adornon mukaan julma, sen voima murskaavaa: "suuret taideteokset ovat onnistumisen auktoriteetillaan säilyttäneet hajottavan valtansa itsellään jonakin, joka on murskaavaa" (ET, 116). Taide lamaannuttaa subjektin, mutta kuten taiteen lume on illusorista, niin on myös sen tuottama tuho. Taiteessa subjekti voi- 
daan tuhota, mutta tuho jää osittaiseksi. Tavallisesti kielletty ja hallittu mimesis tulee tässä prosessissa ikään kuin taiteen objektittoman objektin haltuunottamaksi: erityisesti musiikki ilmaisee tätä objektitonta objektin voimaa subjektin suhteen, manana ja magiana käskevää mahtia. Voimasuhteen kääntyminen immateriaalisen hyväksi on itsessään haurasta ja vaatii subjektiivista ponnistusta. Tästä muistuttaa Schopenhauerin motto: "maailma tarvitsee musiikkia, mutta musiikki ei tarvitse maailmaa". Taiteen mahti ikään kuin aktivoi ulkopuolelta käsin, asettaa mimeettisen suhteen, johon voi vain myöntyä. Kuten suojaväri aktivoituu automaattisesti ja väkivallan todistaminen voi johtaa fyysisesti oirehtivaan traumaan, on autonomisen teoksen murskaava muotokin jotain, joka ottaa valtaansa ja transformoi. Tässä mielessä Esteettinen teoria on teoria katharsiksesta sillä varauksella, että tämä katharsis ei tule suoraan yhteiskunnan fetisistisen rationaliteetin piiriin: "Sikäli kuin maagiset fetissit ovat yksi taiteen yhteiskunnallisista juurista, jää taideteoksiin aineksia sellaisesta fetisismistä, joka nousee tavarafetisismiä vastaan" (ET, 436).

\section{V}

Lopuksi voidaan kysyä, missä määrin modernismin historiallinen rapautuminen vaikuttaa Esteettiseen teoriaan. Yhtäältä Adornon kirjoituksen hienous on paljolti niissä sisällöllisissä oivalluksissa, joita Esteettinen teoria on pullollaan. Toisaalta nämä limittyvät kategorisen ehdottomiin arvostelmiin, joista kaikkia yksikään lukija tuskin jakaa. Lisäksi Adornon näkemykset teoksista ja taitelijoista ovat usein teoreettisina esiintyviä heittoja, jotka lähempää katsottuna osoittautuvat makuarvostelmiksi. Esimerkiksi Beckettin töihin projisoitu totuus "subjektin historiallisesta tilasta" on melko kepeää eksistentialismia, jota toistamalla Adorno leikkii työnsä uskottavuudella (ET, 477). Varsinkin aikalaisiaan arvostellessaan hän rikkookin usein omaa näkemystään, jonka mukaan taidekritiikin kohtalokkaimpia virheitä on sekoittaa taiteen sisältö (Gehalt) taiteilijan sanomaan (ET, 297). Tämä toki on taideteorian kipupiste yleensäkin, ja Adorno myös korostaa taiteen subjektiivisuutta kautta linjan, joten makukysymykset voidaan jättää pitkälti rauhaan. Vakavampana kysymyksenä voi pitää korkea- ja matalakulttuurin rutiininomaista erottamista ja eriävää arvottamista. Nähdäkseni Adornon teoreettisesti radikaaleimmat näkemykset astuvat monta askelta tämän erottelun purkamisen suuntaan, esimerkiksi hänen kirjoittaessaan, ettei raivokas kulttuurikritiikki ole radikaalia: affirmaatio on yksi taiteen momentti (ET, 481-482). Pääasiassa hänen populaarikulttuurin käsittelynsä ei kuitenkaan huomioi tätä ajatusta, vaan jatkaa juuri raivokkaan kritiikin linjoilla. Monissa muissakin kohdin Adorno antaa vihjeitä ehdottomina esittämiensä dikotomioiden purkautumisen välttämättömyydestä vain palatakseen näiden dikotomioiden toistamiseen.

Esteettisen teorian konstellatiivisessa esityksessä voidaan nähdä mahdollisuus kahteen tulkintalinjaan. Adornon teoreettisesti helpommin hyväksyttävät, oleellisesti ambivalenssia ja monimielisyyttä korostavat näkemykset vievät yhteen suuntaan, hänen ehdottomat ja dramaattiset kiteytyksensä toiseen. Lukutavasta riippuen Esteettistä teoriaa voikin lähestyä syvällisenä taideteoriana, jota tosin häiritsee kirjoittajan tapa jatkuvasti eksyä laajojen esimerkkitapausten selvittelyyn, tai sen voi kohdata epäyhtenäisten taidepohdiskelujen aarreaittana, jonka kirjoittaja tosin ottaa itsensä aika vakavasti. Esteettisen asenteen oppimestarina Adorno kuitenkin esittää, ettei nähden kahden välillä tarvitse tehdä valintaa. Vastakohdat läpäisevät toisensa ainoastaan ääripisteidensä kautta, kun taas keskivaiheilla ei tapahdu mitään merkittävää. Tämä on modernin paradoksaalinen ja velvoittava tilanne. Sen vaalijat ovat yhtenäisiä myös ollessaan erimielisiä - ja erityisesti silloin.

Taneli Tuominen 